\title{
Sampah Dalam Kacamata Media Online
}

\author{
Rr. Pramesthi Ratnaningtyas \\ Program Studi Ilmu Komunikasi, Fakultas Ekonomi dan Sosial, Universitas AMIKOM \\ Yogyakarta \\ Jl. Ring Road Utara, Condong Catur, Sleman, Yogyakarta \\ pramesthi@amikom.ac.id
}

Masuk : 31-08-2019, revisi: 24-12-2019, diterima untuk diterbitkan : 26-12-2019

\begin{abstract}
The aim of this research is to explain how Tribunjogja.com constructs and frames the issue of trash (Jogja Darurat Sampah) in the period of March to April 2019. During the time, news articles were narrowed based on the TPST Piyungan tag (\#TPSTPiyungan) until 43 online news stories were obtained on 11 different dates. This study uses a qualitative and constructionistparadigm approach. Agenda Setting theory is employed in conjunction with Entman's framing analysis which has four elements: defining the problem, diagnosing the cause, making moral judgments, and treatment recommendations. The integration of the theories and analysis aims to see the tendency of Tribunjogja.com in responding to problems (of trash) in the society. The results showed that the news revealed the facts of social and economic problems that occur in the community related to trash problems. The closure of TPST Piyungan (integrated landfills) conducted by residents departs from poor trash management. The domino effect is the over accumulation of garbage in temporary landfills (TPS) and depots, even scattering on the road. Economically, this problem disrupts the income of people who have jobs collecting trash from people's homes. This problem is closely related to the economical, social, and sanitation aspects of the wider community. Trash becomes a time bomb that demands government policies that considering the social aspects of local residents of TPST Piyungan, and the wider society.
\end{abstract}

Keywords:framing, news, online media, trash

\begin{abstract}
Abstrak
Penelitian ini bertujuan untuk menjelaskan bagaimana Tribunjogja.com mengonstruksi dan membingkai isu sampah (Jogja Darurat Sampah) pada periode Maret hingga April 2019. Dalam kurun waktu tersebut, artikel berita dipersempit berdasarkan tag TPST Piyungan hingga didapatkan 43 berita daring pada 11 tanggal yang berbeda. Dengan demikian, digunakan pendekatan kualitatif dan paradigma konstruksionis. Teori agenda setting digunakan bersama analisis framing Entman yang memiliki elemen define problems, diagnose causes, make moral judgement, dan treatment recommendation. Penggabungan teori dan analisis tersebut untuk melihat kecenderungan pemberitaan Tribunjogja.com dalam merespon permasalahan di lapangan. Hasil penelitian menunjukkan bahwa berita cenderung memunculkan aspek sosial dan ekonomi. Mengingat penutupan atau blokade TPST Piyungan yang dilakukan warga setempat berangkat dari pengelolaan TPST yang tidak baik. Dampak penutupan itu membuat sampah menggunung di TPS dan depo-depo, bahkan berceceran sampai di jalan. Secara ekonomi, terlihat tertutupnya pendapatan warga yang memiliki pekerjaan jasa pengambilan sampah dari rumah-rumah penduduk. Hal tersebut terkait dengan hajat
\end{abstract}


hidup dan kesehatan masyarakat luas. Sampah menjadi bom waktu yang menuntut kebijakan pemerintah yang tidak menanggalkan aspek sosial bagi warga setempat TPST Piyungan pada khususnya, dan masyarakat luas pada umumnya.

Kata kunci: berita,framing, media daring, sampah

\section{Pendahuluan}

Sampah sudah bukan lagi menjadi permasalahan yang dialami satu negara saja. Mengingat sifatnya yang susah diurai, tapi dengan pasti terus bertambah. Wajar jika pada akhirnya, sampah menjadi permasalahan yang semakin krusial di era milenial ini. Bagaimana hal tersebut tidak terjadi jika populasi manusia semakin tidak terukur. Sejalan dengan pertumbuhan populasi, produksi sampah yang dihasilkan masyarakat pun semakin tidak terkendali. Di saat yang sama, kepedulian dan kebiasaan untuk mendaur ulang sampah masih hanya ditekuni segelintir kelompok masyarakat.

Indonesia sendiri merupakan negara kedua penyumbang sampah terbesar setelah China (Garnesia, 2018). Di saat yang sama, darurat sampah juga terjadi di Yogyakarta. Tempat Pembuangan Sampah Terpadu (TPST) Piyungan Bantul yang merupakan tempat pembuangan sampah dari kota Yogyakarta, kabupaten Bantul, dan kabupaten Sleman semakin tidak memadai.Syambudi (2019) menjelaskan bahwa TPST Piyungan Bantul sudah dibuka sejak tahun 1995. Selama 24 tahun beroperasi, saat ini TPST Piyungan Bantul mengalami kelebihan kapasitas karena volume sampah yang masuk setiap harinya. Terhitung dari bulan Januari hingga Maret 2019, sekitar 580 ton sampah per hari yang masuk ke TPST Piyungan Bantul. Belum lagi momen Lebaran yang bisa mencapai 700 ton. Karenanya, sesuai dengan ketentuan, TPST Piyungan yang memiliki luas 12,5 hektar dan kemudian ditambah 2,5 hektar di tahun 2018, harusnya sudah ditutup tahun 2012 lalu(Riyadi, 2018).

Permasalahan sampah ini sebenarnya sudah terjadi sejak beberapa tahun terakhir. Truk atau mobil pengangkut sampah tidak bisa memasuki TPST Piyungan karena aksesnya ditutup warga. Kendaraan pengangkut sampah akhirnya berbalik arah dan membawa kembali sampah yang diangkut. Hanya saja, di awal tahun 2019 ini permasalahan sampah tersebut semakin menunjukkan 'eksistensinya' sehingga muncul respon masyarakat berupa tagar Jogja Darurat Sampah (\#JogjaDaruratSampah) di berbagai media sosial. Beberapa media massa lokal dan nasionalpun menyoroti permasalahan ini karena banyak tempat pembuangan sampah sementara (TPS), atau depo-depo yang mengalami ledakan sampah. Tempat pembuangan sampah tidak lagi mampu menampung, yang berakibat pada berserakannya sampah sampai ke jalan. Belum lagi, disertai bau yang tidak mengenakkan bagi warga. 


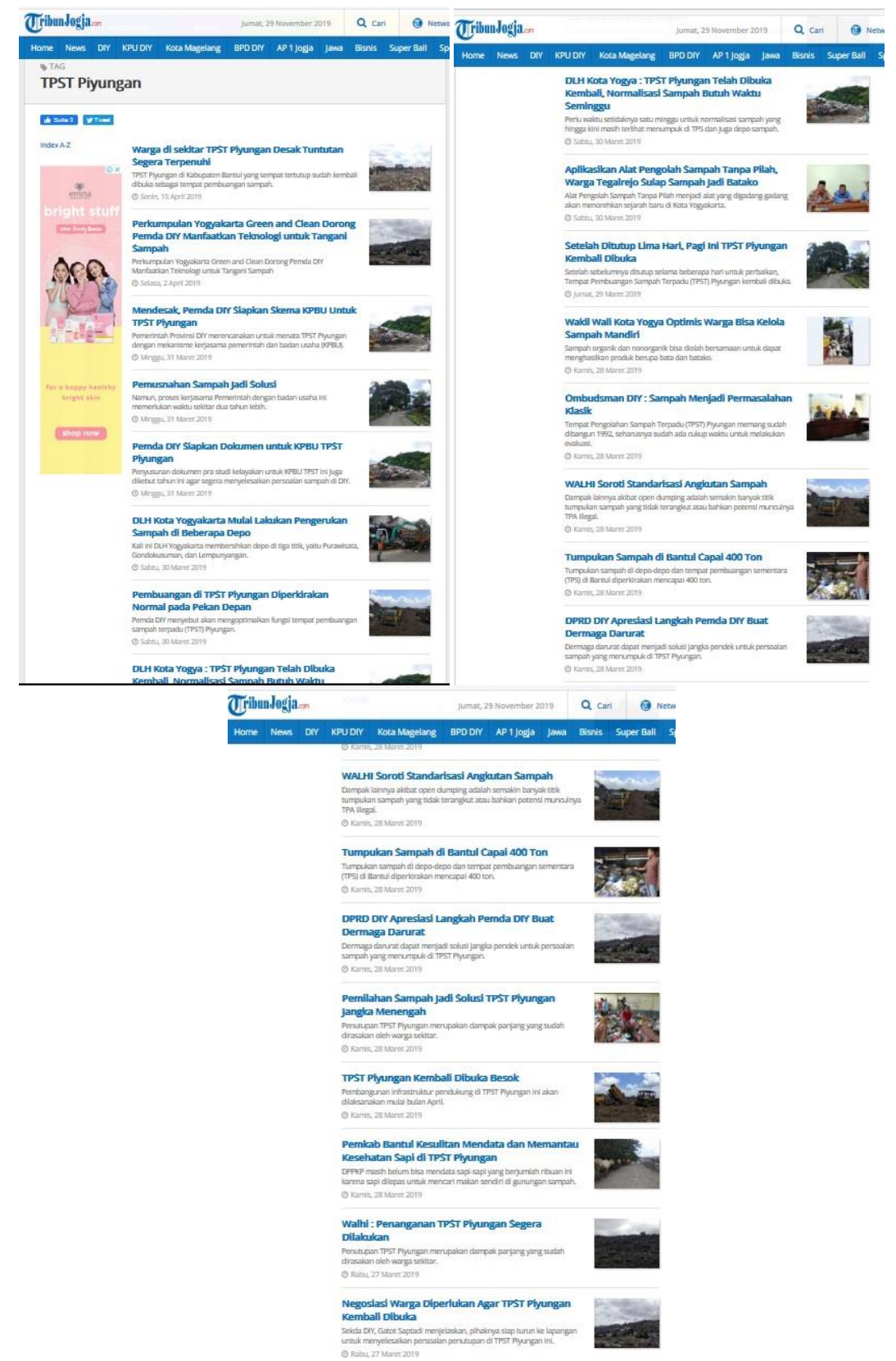

Gambar 1: Beberapa berita terkait isu sampah atau tag TPST Piyungan di Tribunjogja.com. (Sumber: Tribunjogja.com)

Salah satu media daring yang menyoroti permasalahan ini adalah Tribunjogja.com. Media tersebut menyoroti isu darurat sampah di Yogyakarta secara lebih massive dibandingkan media daring lainnya, khususnya dalam kurun waktu bulan Maret hingga April 2019. Jumlah berita yang dimunculkan tribunjogja.com lebih banyak dibandingkan media daring lokal lain, seperti krjogja.com yang hanya menghadirkan enam berita dalam kurun waktu tersebut. Selain itu, ditemukan juga gaya penulisan di Tribunjogja.com yang sedikit berbeda dibandingkan media serupa dalam memberitakan permasalahan sampah 
ini. Hal itu dikarenakan posisi Tribunjogja.com yang sebagai media juga memiliki sudut pandangnya sendiri dalam melihat suatu isu. Ada aspek-aspek yang ditonjolkan dan ada pula aspek-aspek yang dibuang. Berita yang dihadirkan juga menyangkut seleksi beberapa aspek realitas sosial.

Aspek yang ditonjolkan atau dibuang berkaitan dengan keterbatasan media. Sebagaimana yang disampaikan Niklas Luhmann (1996) bahwa media tidak mampu menampung segala hal yang ada dalam realitas pertama dan itu sudah merupakan 'manipulasi'. Media juga mempunyai struktur organisasi, dan reproduksi sendiri. Untuk itu, realitas media menunjukkan bahwa batas antara referensidiri dan referensilain adalah perbedaan. Karenanya, realitas media massa adalah realitas pengamatan tingkat kedua. Realitas tersebut menggantikan pola pengetahuan yang telah disampaikan oleh pihak yang memiliki posisi lebih tepat untuk mengamati seperti pendeta, imam, kaum bangsawan, ataupun oleh kota, agama, dan oleh aspek tertentu, baik secara politis maupun etis. Perbedaannya jelas, seseorang bisa bicara tentang kemunduran atau kemajuan. Demikian juga dalam hal ini, satu-satunya mode yang tertinggal dari pengamatan tingkat kedua adalah observasi. Suatu masyarakat menyerahkan pengamatandirinya kepada sistem fungsi media massa, masuk dalam cara pengamatan pada mode observasi pengamat.

Dalam media juga ada kepentingan untuk melakukan strategi legitimasi dan delegitimasi yang dihadirkan dengan pembentukan wacana. Untuk melakukannya, media melibatkan banyak pihak yang berkepentingan, seperti para profesional dan pemilik media, atau stageholder lainnya. Hadirnya pihak-pihak tersebut, berkaitan dengan tuntutan ideologis atau bisnis (SK, 2014). Di sisi lain, menurut Ashadi Siregar (2008), seorang jurnalis pada hakekatnya adalah pekerja kultural karena berurusan dengan wacana. Dengan demikian, pada tataran teknis proses kerja jurnalis dalam mengolah fakta publik ke informasi jurnalisme digerakkan politik pemberitaan organisasi keredaksiannya. Kondisi tersebut terkait dengan posisi newsroom yang bukan ruang hampa dalam memproduksi berita. Di dalamnya ada kepentingan. Saat ini, jurnalis diwajibkan tunduk pada hukum pasar, mana yang mendapat respon, menarik minat pembaca atau pengiklan maka berita atau rubrik tersebut yang akan dihadirkan.

Kerja jurnalisme yang dilakukan tribunjogja.com adalah bentuk jurnalisme daring (online) yang merupakan jurnalistik ketiga setelah cetak dan elektronik. Jurnalime daring memiliki nilai tawar tersendiri di era milenial karena kehadirannya yang mampu mengubah wajah jurnalisme di tingkat global dan lokal, termasuk Indonesia. Hanya saja ada pendangkalan kualitas yang semakin menguat seiring berkembangnya bentuk jurnalisme ini. Hal tersebut dikarenakan menambah kerumitan di tengah keterpurukan jurnalisme konvensional. Banyaknya informasi yang dihasilkan juga memerlukan pemahaman ulang mengenai bagaimana menyikapi berita. Mengingat perubahan praktik jurnalisme online berbeda dengan konvensional (Lindawati, 2018).

Iskandar dan Lestari (2016) melihat tuntutan pemodal juga membuat profesi wartawan menjadi mekanistik untuk terus memproduksi berita. Tulisan yang bagus, dan memiliki analisis mendalam bukan lagi prioritas kalau ujungnya tidak laku dijual. Berita pesanan bukan menjadi masalah, karena menjadi 
pendiktean kekuatan modal. Tentunya juga berkaitan dengan kepentingan masingmasing kelompok karena ada agenda terselubung di dalamnya. Hal tersebut tidak lepas dari adanya agenda setting yang merupakan teori yang diperkenalkan Maxwell McCombs dan Donald Shaw pada tahun 1972. Agendasetting menekankan pada hubungan antara berita yang disampaikan media dengan isu yang dinilai penting oleh publik. Bukan media yang tidak secara sengaja mempengaruhi publik, melainkan khalayak mempercayakan atau meminta para profesional pekerja media ke mana masyarakat harus memfokuskan perhatiannya. Teori ini terjadi karena peran media yang menjadi penjaga gawang informasi, sehingga harus selektif dalam menyampaikan berita. Dengan demikian, maka agenda setting berupaya membangun isu umum penting, yang kemudian membingkainya ke dalam bagian-bagian atau aspek-aspek yang dinilai penting (Morissan, 2013).

Dalam media baru atau daring, hubungan antara media dan publik adalah saling mempengaruhi. Media memiliki kekuatan atau kemampuan untuk membentuk agenda publik berdasarkan kedekatan dengan pemerintahan, korporasi atau kelompok kepentingan tertentu. Bisa juga melalui penilaian dan penelitian terkait minat serta pola konsumsi masyarakat terhadap informasi. Pastinya, agenda media yang dibangun tidak dalam kekosongan (Littlejohn \& Foss, 2009). Keterkaitan hubungan antara media dengan sumber kekuasaan di luar media terbagi dalam empat tipe. Pertama, sumber kekuasaan luar besar, kekuasaan media besar yang merupakan kedekatan pemilik media dengan pejabat publik. Jika keduanya bekerjasama maka akan memberikan pengaruh sangat besar terhadap agenda publik. Kedua, sumber kekuasaan luar besar, kekuasaan media kecil. Dalam artian, sumber kekuasaan luar (politisi, partai politik) menggunakan (kooptasi) media untuk mencapai tujuannya dengan memasang iklan atau menjadi sponsor program tertentu. Ketiga, sumber kekuasaan luar kecil, kekuasaan media besar yang menempatkan posisi media sebagai penentu. Media dapat mengabaikan atau memberitakan suatu peristiwa penting di masyarakat. Keempat, sumber kekuasaan luar dan media sama-sama kecil menempatkan agenda publik ditentukan oleh peristiwa itu sendiri (Morissan, 2013).

Pertemuan teknologi komunikasi dengan praktik jurnalisme yang memunculkan jurnalisme daring juga membawa dampak perubahan konstelasi media yang tidak hanya pada level relasi organisasi media, tapi juga pesan yang diakses masyarakat. Berita menjadi dinamis dan konstekstual dari segi waktu dan ruang selama ada broadband dan jaringan internet. Iskandar dan Lestari (2016) melihat ada beberapa karakter media daring yakni, halaman tidak terbatas, audience control, non-lienarity, berita dapat diakses kembali, immediacy, adanya interaksi antara pembaca dengan redaksi melalui kolom komentar, serta memungkinkan sajian berupa teks, suara, gambar, video, dan komponen lain sekaligus. 


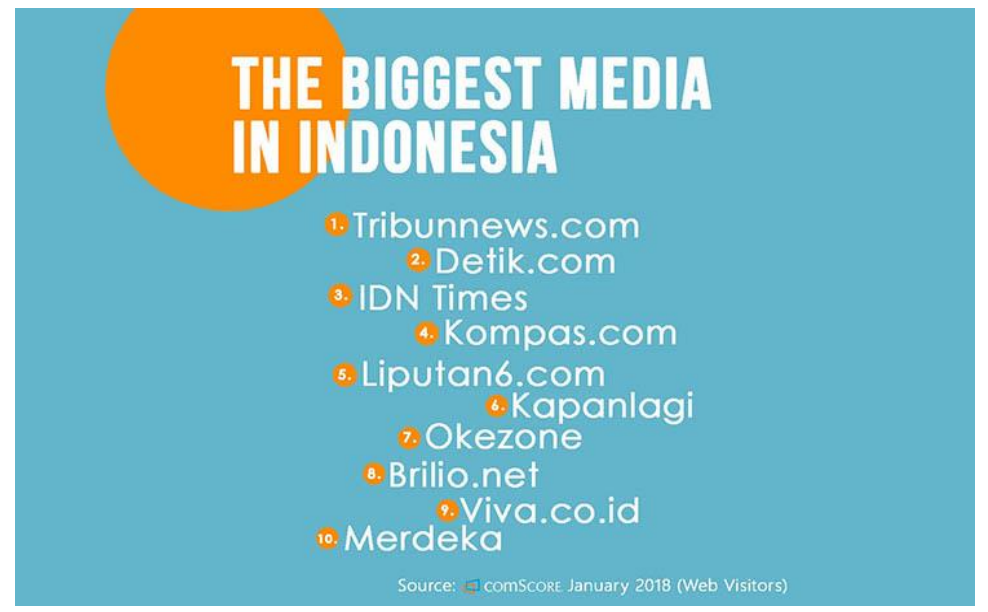

Gambar 2: $\quad$ Top 10 Online Media in Indonesia (sumber Teknorush.com, Maret 2018)

Tribunjogja.com sendiri merupakan subdomain Tribunnews.com yang memiliki fokus untuk memberitakan peristiwa di suatu daerah tertentu. Media online tersebut berada di peringkat pertama dari 10 media daring yang paling banyak dikunjungi versi ComScore pada Januari 2018(Portnoy, 2018). Dalam situs Alexa.com yang diakses bulan Juli 2019 (Topsites, 2019), Tribunnews.com berada di peringkat pertama situs-situs teratas di Indonesia. Selain itu, berada di peringkat kedua setelah Detik.com pada 500 situs teratas di situs dengan kategori World/BahasaIndonesia/Berita/Online. Dengan posisinya tersebut, Tribunjogja.com memiliki posisi strategis dalam memilihkan isu bagi pembacanya. Dengan demikian, makaperlu untuk mengetahui bagaimana Tribunjogja.com menyeleksi isu dan menonjolkan aspek-aspek dalam berita. Berdasarkan permasalahan tersebut, penelitian ini ingin melihat bagaimana Tribunjogja.com mengonstruksi dan membingkai isu sampah (Jogja Darurat Sampah) dalam kurun waktu Maret hingga April 2019.

\section{Metode Penelitian}

Penelitian ini menggunakan paradigma konstruksionis yang memandang realitas sosial merupakan hasil konstruksi. Paradigma ini juga melihat komunikasi sebagai suatu produksi dan pertukaran makna. Karenanya, realitas adalah sesuatu yang dikonstruksi atau diproduksi. Wartawan secara aktif mendefinisikan dan memproduksi suatu peristiwa karena fakta ada dalam konsepsi pikiran seseorang. Konstruksi itu yang kemudian ditambah dengan pencarian bukti-bukti. Fakta adalah konstruksi suatu realitas, yang kebenarannya bersifat relatif karena berlaku sesuai konteks tertentu (Eriyanto, 2011). Pandangan ini juga melihat media sebagai agen, lengkap dengan pandangan, bias dan kepemihakannya dalam mengkonstruksi pesan.

Berdasarkan paradigma tersebut, maka penelitian ini menggunakan pendekatan kualitatif dengan metode analisis framing.Eriyanto (2011) menjelaskan analisis framing adalah metode analisis teks. Fokus analisis pada bagaimana realitas dikonstruksi dan menggunakan cara apa konstruksi itu dibentuk. Framing adalah cara bagaimana peristiwa disajikan media dengan 
menekankan pada bagian tertentu, aspek tertentu dan membesarkan cara bercerita suatu realitas. Karenanya, framing merupakan suatu pendekatan untuk mengetahui cara pandang wartawan dalam menyeleksi isu dan menulis berita. Cara pandang tersebut pada akhirnya menentukan fakta apa yang diambil, bagian mana yang ditonjolkan dan dihilangkan. Framing memiliki dua aspek yakni, ada fakta atau realitas yang dipilih dan bagaimana fakta tersebut disajikan kepada pembaca. Salah satu tokohnya adalah Robert N Entman yang menjelaskan bahwa framing adalah proses seleksi dari berbagai aspek realitas, sehingga hanya bagian tertentu yang lebih menonjol dibandingkan aspek lainnya (Eriyanto, 2011). Bentuk penonjolan beragam yakni menempatkan satu aspek informasi lebih menonjol dibandingkan lainnya, lebih mencolok, adanya pengulangan informasi yang dipandang penting atau dihubungkan dengan aspek budaya yang akrab di benak masyarakat (Eriyanto, 2011). Sebagaimana yang Entman sampaikan bahwa;

Texts can make bits of information more salient by placement or repetition, or by associating them with culturally familiar symbols (Entman, 1993).

Dijelaskan pula bahwa pemahaman tentang framingdapat membantu menjelaskan banyaknya perdebatan yang empiris dan normatif. Hal yang paling penting adalah karena konsep framing mengarahkan perhatian pada detail bagaimana teks yang dikomunikasikan menunjukkan kekuatannya (Entman, 1993). Konsepsi framing Entman sendiri meliputi define problems, merupakan bingkai paling utama yang menekankan bagaimana peristiwa dipahami oleh wartawan. Diagnose causes, memperkirakan penyebab masalah. Elemen framing ini membingkai siapa yang dianggap aktor pelaku dan siapa yang dianggap korban. Penyebab disini bisa berarti apa (what), atau siapa (who). Make moral judgement adalah elemen yang digunakan untuk membenarkan atau memberikan argumen pada pendefinisian masalah yang dibuat. Elemen lainnya adalah treatment recommendation (menekankan penyelesaian) yang digunakan untuk menilai apa yang dikehendaki wartawan (Eriyanto, 2011).

Penelitian ini berfokus pada isu sampah dari teks berita Tribunjogja.com yang terjadi selama bulan Maret-April 2019. Berita yang ditemukan dipersempit lagi berdasarkan tag TPST Piyungan.Hingga didapatkan 43 berita daring pada 11 tanggal yang berbeda. Sebanyak 43 berita tersebut kemudian dianalisis menggunakan analisis framing Entman. Diawali dengan analisis berita menggunakan elemen define problems untuk melihat bagaimana peristiwa dipahami oleh wartawan, atau bagaimana realita didefinisikan oleh Tribunjogja.com. Elemen kedua yakni diagnose cause digunakan untuk melihat penyebab masalah yang bisa berupa apa dan siapa. Selanjutnya, melalui elemen ketiga make moral judgement, peneliti melihat nilai moral yang digunakan untuk melegitimasi dan mendelegitimasi tindakan. Terakhir, treatment recommendation untuk melihat solusi yang ditawarkan.

\section{Hasil Penemuan Dan Diskusi}

Hasil penelitian yang berdasarkan elemen define problem memperlihatkan bagaimana Tribunjogja.com memunculkan isu terkait ditutupnya TPST Piyungan 
karena sudah over capacity yang berakibat pada penumpukan sampah, tersendatnya proses buang serta bongkar sampah hingga menumpuknya sampah di TPS dan depo-depo sampah. Tribunjogja.com mengawali permasalahan sampah tersebut melalui rentetan lima berita dari tanggal 24 hingga 25 Maret 2019. Media daring tersebut sengaja mengarahkan dan mempengaruhi khalayak pembaca tentang isu sampah agar masyarakat menyadari adanya bom waktu yang akan segera meledak. Permasalahan yang dihadirkan pada pemberitaan di Tribunjogja.com diawali dengan tidak adanya aktivitas di TPST Piyungan seperti biasanya. Palang penutup jalan yang menuju TPST Piyungan sengaja ditutup, sehingga dump truk pengangkut sampah tidak masuk. Di saat yang sama terjadi penumpukan sampah di sejumlah pasar atau depo pembuangan sampah. Beberapa depo juga sudah tidak dapat menampung, dan berakibat pada tumpukan sampah sampai dipinggir jalan. Pemberitaan selama dua hari tersebut mencoba membuat masyarakat memfokuskan perhatiannya pada realita yang akan diungkapkan Tribunjogja.com pada pemberitaan selanjutnya, yakni keharusan adanya upaya untuk menyelesaikan permasalahan tersebut. Sultan selaku gubernur DIY dan Bupati Bantul pun turut ambil bagian dari permasalahan yang terus "mengular" dengan membuat tim dan berkoordinasi antara provinsi dan kabupaten/kota.

Berita tentang isu sampah yang paling banyak dimunculkan Tribunjogja.com ada di tanggal 27 Maret 2019. Pada tanggal tersebut, sebanyak 12 berita hadir dan memfokuskan pemberitaan pada permasalahan dari darurat sampah yang terus bergulir dengan penumpukan sampah yang kian tak terkendali. Permintaan warga sekitar TPST Piyungan untuk diperhatikan dan pengelolaan sampah yang telah menggunung juga tak luput dari perhatian media yang berada di bawah naungan PT. Tribun Digital Online, Divisi Koran Daerah Kompas Gramedia (Group of Regional Newspaper) ini.Pemberitaan yang sedikit anti klimaks dimulai pada tanggal 28 Maret 2019 yang membahas tentang akan dibukanya kembali TPST Piyungan pada hari Jumat (tanggal 29 Maret 2019) dengan berbagai kemungkinan pengelolaan sampah, khususnya untuk jangka pendek. Untuk itu, pada pemberitaan berikutnya, Tribunjogja.com memfokuskan diri pada situasi pembukaan TPST Piyungan, normalisasi tumpukan sampah dengan berbagai mekanismenya, solusi dan teknologi yang mungkin dapat digunakan hingga tuntutan warga sekitar tentang pengelolaan sampah.Dari temuan tersebut, dapat disimpulkan bahwa berita yang dimuat Tribunjogja.com mengalami proses redaksional terlebih dahulu. Setiap berita yang dihadirkan tidak lepas dari rapat redaksi, penugasan wartawan, proses penyaringan informasi oleh gatekeeper, dan baru kemudian diterbitkan agar bisa dibaca khalayak luas. Proses tersebut berkaitan dengan ideologi media.Ada strategi yang dikembangkan wartawan, reporter, atau editor dalam setiap isu yang akan dihadirkan. Strategi yang tidak lepas dari pengaruh internal dan/atau eksternal di media, yang di dalamnya terdapat pemilihan kata dan bahasa. Dalam setiap berita yang termuat, ada citra yang ingin dihadirkan, sekaligus kepentingan yang diupayakan pemilik pesan (AR, 2014).

Dengan demikian, Tribunjogja.com menerapkan agenda setting dengan membangun tema yakni isu sampah. Isu yang kemudian dibingkai dalam berbagai aspek penting seperti penutupan TPST Piyungan dan dampaknya, permasalahan 
sampah yang kian menggunung setiap harinya, warga setempat TPST Piyungan yang minta diperhatikan, solusi jangka pendek, sekaligus regulasi dan teknologi yang diharapkan bisa menyelesaikan permasalahan tersebut. Media daring ini juga memfokuskan diri untuk menggelontorkan isu sampah secara bertahap dan gencar. Pilihan fakta yang dihadirkan, sudah dikonstruksi dan memiliki sudut pandang tersendiri. Misalnya, penutupan TPST Piyungan, permintaan warga sekitar hingga solusi dan normalisasi.Dengan demikian, isu sampah (\#JogjaDaruratSampah) merupakan peristiwa yang dipahami oleh wartawan sebagai suatu kejadian atau peristiwa yang menarik, sekaligus memiliki kepentingan publik. Wacana yang muncul dari berita-berita tersebut mengindikasikan bahwa isu sampah bukan masalah segelintir orang atau kelompok. Mengingat kata kunci yang kerap muncul adalah TPST Piyungan ditutup dan penumpukan sampah.

Elemen framing kedua,diagnose causes membingkai penyebab dari munculnya isu sampah (\#JogjaDaruratSampah) yakni pengelolaan sampah yang tidak beres, dan berakibat pada tindakan warga sekitar untuk memblokade TPST Piyungan selama beberapa hari. Dari penyebab tersebut, pengelola TPST Piyungan dan pemerintah dianggap lalai sehingga merugikan warga sekitar. Kondisi yang berujung panjang karena pada akhirnya penutupan TPST Piyungan tersebut juga memberi dampak pada masyarakat luas. Warga sekitar TPST Piyungan yang awalnya menjadi korban pun, pada akhirnya juga menjadi pelaku karena aksi mereka memblokade lokasi pembuangan sampah terakhir. Hal ini yang membuat sampah berserakan dimana-mana. Kondisi tersebut menyebabkan munculnya ketidaknyamanan masyarakat luas. Beberapa berita yang menempatkan warga sekitar TPST Piyungan sebagai pelaku adalah "Warga Keluhkan Soal Sampah Akibat TPST Piyungan Ditutup", "TPST Piyungan Ditutup, Paguyuban Jasa Ambil Sampah Tak Bisa Buang 450 Ton Sampah", "Soal TPST Piyungan Ditutup, Begini Kata Bupati Bantul". Tingkatan yang mempengaruhi framing wartawan dan Tribunjogja.com juga terlihat dari isi berita. Ada beberapa berita yang konten dan narasumbernya merupakan pengulangan dari berita yang telah dimuat sebelumnya. Salah satunya berita berjudul "Walhi : Penanganan TPST Piyungan Segera Dilakukan" yang rilis pada tanggal 27 Maret 2019 jam 22.24. Berita tersebut memiliki isi yang sama persis dengan berita berjudul "Walhi Soroti Standarisasi Angkutan Sampah" yang rilis pada tanggal 28 Maret 2019 jam 21.03. Adapula berita berjudul "Mendesak, Pemda DIY Siapkan Skema KPBU untuk TPST Piyungan yang muncul pada tanggal 31 Maret 2019 jam 17.43. Berita tersebut memiliki isi berita yang merupakan gabungan dari berita berjudul "Pemda DIY Siapkan Dokumen untuk KPBU TPST Piyungan yang rilis tanggal 31 Maret 2019 jam 15.41 dan "Penanganan TPST Piyungan Tunggu Proses Lelang Bulan April” yang muncul tanggal 27 Maret 2019 jam 21.49 .

Elemen make moral judgement digunakan untuk membenarkan atau memberikan argumen pada pendefinisian masalah yang dibuat. Pada elemen ini serangkaian pemberitaan isu sampah di Tribunjogja.com memperlihatkan adanya unsur kesengajaan, tidak ada unsur keadilan, bom waktu, minimnya kesadaran masyarakat pada pengurangan, pemilahan sampah di lingkup terkecil. Unsur 
kesengajaan dan ketidakadilan ketika warga sekitar TPST Piyungan dengan sadar memblokade sehingga tidak ada aktivitas pembuangan sampah dari pihak luar, kecuali armada truk pengangkut sampah di sekitar lokasi. Kesengajaan juga berkaitan erat dengan perilaku masyarakat luas, yang memang secara sadar membuang sampah tanpa pemilahan terlebih dahulu. Terkadang malah membuang sampah sembarangan. Sampah yang terus menggunung tanpa adanya pengelolaan yang benar tersebut hanya menjadi bom waktu yang dirasakan masyarakat luas.

Dalam pemberitaan tersebut, wartawan dan Tribunjogja.com juga menempatkan dirinya dalam jurnalisme lingkungan. Berita yang dihadirkan membawa pemangku kebijakan, aktivis lingkungan dengan kompleksitas isu yang menggunakan teknologi atau wacana kebijakan publik. Santana (2017) mengungkapkan bahwa isu lingkungan media diformat untuk isu kebijakan publik dengan melibatkan peran pemerintah, organisasi lingkungan dan pebisnis. Karenanya, dalam pemberitaannya, Tribunjogja.com melalui wartawan lebih memilih realita tertentu dan narasumber yang memiliki pernyataan dengan daya gugah bagi pembaca. Tentunya, tanpa menanggalkan kesan yang menarik. Narasumber yang dipilih oleh Tribunjogja.com adalah Gubernur DIYSri Sultan Hamengku Buwono X, Wakil Walikota YogyakartaDrs Heroe Poerwadi MA, Bupati Bantul Drs Suharsono, Sekda DIY Gatot Saptadi, Sekda Bantul Helmi Jamharis, Ketua DPRD DIY Yoeke Indra Agung Laksana, Kepala Dinas Lingkungan Hidup Kota Yogyakarta Suyana, Direktur Wahana Lingkungan Hidup (Walhi) DIY Halik Sandera, Sekretaris Perkumpulan Yogyakarta Green and Clean Erwanto Widyarto, perwakilan masyarakat dan komunitas. Luhmann (1996) menjelaskan bahwa realitas media massa adalah realitas pengamatan tingkat kedua. Realitas tersebut menggantikan pola pengetahuan yang telah disampaikan oleh pihak yang memiliki posisi lebih tepat untuk mengamati. Begitu pula dengan Tribunjogja.com yang menghadirkan narasumber pilihannya, mengolah pernyataan dan menghadirkannya aspek-aspek tertentu.

Terakhir, dalam elemen treatment recommendation, permasalahan sampah yang digelontorkan Tribunjogja.com ini menyangkut semua kalangan, meliputi masyarakat setempat, akademisi, pemerintah, komunitas dan sebagainya. Sampah yang bukan masalah satu orang atau kelompok ini menjadi masalah bersama yang solusinya memerlukan kolaborasi pentahelix antara akademisi, pemerintah, masyarakat atau komunitas, pengusaha, dan media. Secara teknis, solusi yang direkomendasikan dan bisa diterapkan bersama oleh segenap pemangku kebijakan maupun masyarakat, diantaranya adalah pemerintah atau pengelola TPST Piyungan harus menerapkan standarisasi angkutan sampah dan segera memperbaiki maupun memodernisasi metode pengelolalan sampah. Pemerintah juga harus memperbaiki akses jalan ke TPST Piyungan. Selain itu, perlu menambah alat berat dan menerapkan teknologi tepat guna. Mempersiapkan lahan alternatif baru, dan perlu adanya pengaturan mekanisme pembuangan sampah per wilayah kabupaten/kota dirasa penting menjadi salah satu solusi. Di saat yang sama, pemerintah hendaknya memberi dana kompensasi bagi warga sekitar TPST Piyungan yang dirugikan. Selain itu, agar pengelolaan bisa memberikan banyak manfaat, maka pemerintah perlu menggandeng rekanan atau pengusaha yang kredibel untuk mengelola sampah secara profesional. Sedangkan masyarakat 
harus berperan aktif dalam pengelolaan sampah rumah tangga. Peran serta NGO atau lembaga terkait juga perlu, khususnya untuk mengawasi pengelolaan sampah serta mengedukasi masyarakat tentang pengelolaan sampah dan pola hidup zero waste. Rangkuman mengenai Tribunjogja.com mengkronstruksi dan membingkai isu sampah dapat dilihat pada tabel 1 di bawah ini.

Tabel 1. Frame Isu Sampah di Tribunjogja.com

\begin{tabular}{|c|c|}
\hline Komponen Framing & Isu Sampah di Tribunjogja.com \\
\hline Define problem & $\begin{array}{l}\text { - Tidak adanya aktivitas di TPST Piyungan. } \\
\text { - TPST Piyungan karena sudah over capacity yang } \\
\text { berakibat pada penumpukan sampah. } \\
\text { - Tersendatnya proses buang dan bongkar sampah. } \\
\text { - Menumpuknya sampah di TPS dan depo-depo } \\
\text { - Sampah. } \\
\text { - Sampah adalah bom waktu yang segera meledak. }\end{array}$ \\
\hline Diagnose causes & $\begin{array}{l}\text { - Pengelola TPST Piyungan dan pemerintah } \\
\text { dianggap lalai. } \\
\text { - Pengelolaan sampah yang tidak beres. } \\
\text { - Warga sekitar memblokade TPST Piyungan selama } \\
\text { beberapa hari. }\end{array}$ \\
\hline Make moral judgement & $\begin{array}{l}\text { - Memperlihatkan adanya unsur kesengajaan. } \\
\text { - Tidak ada unsur keadilan. } \\
\text { - Minimnya kesadaran masyarakat pada pengurangan } \\
\text { sampah. } \\
\text { - Pemilahan sampah di lingkup terkecil. }\end{array}$ \\
\hline Treatment recommendation & $\begin{array}{l}\text { - Sampah bukan masalah satu orang atau kelompok. } \\
\text { - Sampah masalah bersama yang solusinya } \\
\text { memerlukan kolaborasi pentahelix antara } \\
\text { akademisi, pemerintah, masyarakat atau komunitas, } \\
\text { pengusaha, dan media. } \\
\text { - Pemerintah atau pengelola TPST harus menerapkan } \\
\text { standarisasi angkutan sampah. } \\
\text { - Segera memperbaiki maupun memodernisasi } \\
\text { metode pengelolalan sampah. } \\
\text { - Pemerintah juga harus memperbaiki akses jalan ke } \\
\text { TPST. } \\
\text { - Menambah alat berat dan menerapkan teknologi } \\
\text { tepat guna. } \\
\text { - Mempersiapkan lahan alternatif baru. }\end{array}$ \\
\hline
\end{tabular}

Tribunjogja.com sebagai media, tidak hidup di ruang yang hampa atau kosong. Ada hubungan yang saling mempengaruhi antara Tribunjogja.com dengan publik. Berita yang dimunculkan bersinggungan dengan minat dan pola konsumsi terhadap perkembangan isu sampah yang terkait peristiwa atau kejadian yang nyata di kehidupan khalayak masyarakat. Publik yang tertarik untuk mengetahui harus patuh melihat atau membaca rangkaian berita dari susunan program media. Pada akhirnya, media sukses mengkonstruksi realitas peristiwa karena beritanya dibaca banyak orang. Di saat yang sama, terjadi proses 
komodifikasi. Nilai manfaat informasi berubah menjadi nilai tukar (AR, 2014).Untuk memperkuat pemberitaan tentang isu, Tribunjogja.com juga menempatkan dirinya sebagai penentu untuk memilih siapa narasumber yang berkompeten. Realitas kedua yang dihadirkan melalui pemilihan narasumber ditujukan agar pembaca berita Tribunjogja.com menjadi percaya bahwa sampah adalah bom waktu yang akan segera meledak. Sebagaimana yang disampaikan Morissan (2013) bahwa kekuasaan media besar yang menempatkan posisi media sebagai penentu. Media dapat mengabaikan atau memberitakan suatu peristiwa penting di masyarakat.

\section{Simpulan}

Berdasarkan hasil penelitian dan pembahasan di atas, diperoleh kesimpulan bahwa pada elemen define problem, media daring ini memfokuskan diri untuk menggelontorkan isu sampah secara bertahap dan gencar. Fakta yang dihadirkan sudah dikonstruksi dan memiliki sudut pandang tersendiri. Misalnya, penutupan TPST Piyungan, permintaan warga sekitar hingga solusi dan normalisasi. Isu sampah menjadi peristiwa yang dipahami wartawan sebagai suatu kejadian atau peristiwa yang menarik, sekaligus memiliki kepentingan publik. Pada elemen diagnose causes, pembingkaian isu berfokus pada masalah pengelolaan sampah yang mengakibatkan TPST Piyungan diblokade selama beberapa hari. Adanya unsur kesengajaan, tidak ada unsur keadilan, minimnya kesadaran masyarakat pada pengurangan, pemilahan sampah di lingkup terkecil merupakan elemen make moral judgement.Terakhir, pada elemen treatment recommendationmenekankan isu pada kebijakan pemerintah yang jangan hanya jangka pendek, tapi juga jangka panjang, mengingat permasalahan sampah ini tidak hanya terjadi di tahun 2019 saja. Tahun-tahun sebelumnya juga telah terjadi penutupan TPST Piyungan. Selain itu, perlu untuk memanfaatkan teknologi agar bisa mengurangi dan mengubah sampah menjadi sesuatu yang lebih berguna. Dengan demikian, penonjolan aspek yang ditampilkan Tribunjogja.com lebih pada sosial dan ekonomi. Aspek sosial berkaitan dengan hajat hidup masyarakat luas dan sanitasi sebagai akibat penutupan TPST Piyungan. Sampah menjadi bom waktu yang disebabkan dan diakibatkan oleh masyarakat itu sendiri. Secara ekonomi, terlihat tertutupnya rejeki jasa pengambilan sampah karena penutupan TPST Piyungan.

Penelitian ini juga bisa menjadi masukan bagi pihak media yang dalam hal ini adalah Tribunjogja.com untuk lebih berhati-hati dalam mengunggah berita. Tentunya, agar berita yang isinya sama tidak muncul dua kali. Pemilihan narasumber bisa lebih bervariatif, seperti wirausahawan yang menggunakan sampah sebagai bahan produksi. Sosok-sosok kreatif yang mampu mengelola sampah menjadi barang yang lebih berdayaguna. Sebagai contoh, mengubah sampah plastik menjadi tas, mengubah sampah organik menjadi pupuk, dan sebagainya. Hadirnya narasumber yang merupakan insan kreatif bisa menjadi solusi dibalik isu sampah. Penting bagi media untuk juga memberikan solusi isu atau permasalahan yang dimunculkan. Dengan demikian, maka penelitian terkait isu sampah bisa dilakukan kembali karena adanya sudut pandang berbeda 
dariperistiwa atau kejadian baru terkait sampah. Selain itu, bisa juga meluaskan isu sampah tidak hanya di tingkat daerah, tapi juga nasional atau internasional.

\section{Ucapan Terima Kasih}

Peneliti mengucapkan terima kasih kepada semuapihak yang membantuterlaksananya penelitian hingga terpublikasikan, khususnya Prodi Ilmu Komunikasi, Fakultas Ekonomi dan Sosial, sertaDirektorat Lembaga Penelitian Universitas AMIKOM Yogyakarta, J1. Ring Road Utara, Condong Catur, Sleman, Yogyakarta.

\section{Daftar Pustaka}

AR, Fikri. M. (2014). War As Entertainment: Cermatan Terhadap Pemberitaan Isu Teror Dalam New Media. Jurnal Komunikasi, Vol 6, No. 3, 7484.https://journal.untar.ac.id/index.php/komunikasi/article/view/41/0

Entman, R. M. (1993). Framing: Toward Clarification of a Fractured Paradigm. Journal of Communication, 51-58.https://doi.org/10.1111/j.14602466.1993.tb01304.x

Eriyanto. (2011). Analisis Framing : Konstruksi, Ideologi, dan Politik Media. Yogyakarta: LKiS Yogyakarta.

Garnesia, I. (2018, Februari 20). Mengintip Kota-kota Gudang Sampah di Indonesia. Retrieved April 27, 2019, from tirto.id: https://tirto.id/mengintip-kota-kota-gudang-sampah-di-indonesia-cE4o

Iskandar, D. S., \& Lestari, R. (2016). Mitos Jurnalisme. Yogyakarta: Penerbit Andi.

Lindawati, L. (2018). Menakar Kepentingan Publik dalam Jurnalisme Online Berkualitas. In K. Ambard, G. D. Parahita, L. Lindawati, \& A. W. Sukarno, Kualitas Jurnalisme Publik di Media Online: Kasus Indonesia (pp. 85-114). Yogyakarta: UGM Press.

Littlejohn, S. W., \& Foss, K. A. (2009). Encyclopedia of Communication Theory. California: SAGE Publications Inc.

Luhmann, N. (1996). The Reality of The Mass Media. Stanford California: University Press.

Morissan. (2013). Teori Komunikasi Individu Hiingga Massa. Jakarta: Prenadamedia Group.

Portnoy, M. (2018, Maret 2). Media-online-indonesia. Retrieved Juli 29, 2019, from www.teknorush.com: https://teknorush.com/media-online-indonesia/

Riyadi, S. (2018, Juni 21). KRJogja.com. Retrieved April 5, 2019, from Pemerintah Harus Mencari Solusi Baru : 'Overload', TPST Piyungan Mestinya https://krjogja.com/web/news/read/69715/Overload_TPST_Piyungan_Mes tinya_Tutup

Santana, S. (2017). Jurnalisme Kontemporer Edisi 2. Jakarta: Yayasan Pustaka Obor Indonesia. 
Siregar, A. (2008). Pemberitaan Media Pers Indonesia : Paradigma, Epistemologi, Ruang Publik dan Pendekatan Multikultural. Dalam E. Gazali, I. G. Putra, B. Irawanto, P. Rianto, Masduki, A. Darmanto, et al., Media, Komunikasi, dan Politik Sebuah Kajian Kritis (hal. 161-178). Yogya: Fisipol UGM.

Sk, I. (2014). Media dan Kekuasaan. Jakarta: Kompas.

Syambudi, I. (2019, Maret 28). Tirto.id. Retrieved April 5, 2019, from Di Balik Protes Warga yang Berujung Penutupan Akses TPST Piyungan: https://tirto.id/di-balik-protes-warga-yang-berujung-penutupan-akses-tpstpiyungan-dkoR

Topsites. (2019, Juli 3). Retrieved Juli 10, 2019, from www.alexa.com: http://www.alexa.com/topsites/countries/ID 